ISSN 0206-5657. Вісник Львівського університету. Серія біологічна. 2018 Випуск 79. С. 106-113 Visnyk of the Lviv University. Series Biology. 2018. Issue 79. P. 106-113

ЗООЛОГІЯ

УДК [577.151.6: 597.21.5 ]:591.185.2

\begin{abstract}
ЗМІНА ВМІСТУ ЗАГАЛЬНИХ ЛІПІДІВ, ГЛІКОГЕНУ І БІЛКА
У ТКАНИНАХ ПЛІТКИ RUTILUS RUTILUS, LINNAEUS, 1758 ЗА СУМІСНОЇ ДІЇ ТЕМПЕРАТУРИ ТА МІНЕРАЛІЗАЦІї ВОДИ
\end{abstract}

\author{
Ю. Худіяш, М. Причепа, О. Потрохов, О. Зіньковський \\ Інститут гідробіології НАН України \\ nросn. Героїв Сталінграда, 12, Київ 04210, Україна \\ e-mail:yurahud@ukr.net
}

Розглянуто сумісну дію температури та мінералізації води на вміст глікогену, ліпідів і білка у тканинах плітки Rutilus rutilus, Linnaeus, 1758. За результатами досліджень встановлено, що сумісна дія температури і мінералізації води мають більший ефект впливу на баланс зазначених сполук, ніж їхня окрема дія. Особливо це було характерно для піддослідних груп, які перебували у воді нетипової та підвищеної температури $27-32{ }^{\circ} \mathrm{C}$ і низької мінералізації 260 мг/дм³. Показано, що для плітки оптимальними умовами в літній період $є$ температура води $21-23{ }^{\circ} \mathrm{C}$ та іії мінералізація на рівні $260 \mathrm{мг} /$ дм $^{3}$.

Було встановлено, що залучення білкових субстратів і глікогену на енергетичні потреби організму сприяли зростанню загального пулу ліпідів за рахунок використання продуктів метаболізму білкового та вуглеводневого обміну. Було показано, що на перших етапах пристосування плітки до помірних температур $\left(25-30{ }^{\circ} \mathrm{C}\right)$ вміст цих сполук або залишається на попередньому рівні, або збільшується залежно від мінералізації води. На другому етапі, коли температура води значно перевищує кліматичні рівні та досягає $27-32{ }^{\circ} \mathrm{C}$, для успішної адаптації до наявних умов необхідні додаткові енерговитрати, вміст запасних речовин і насамперед глікогену, який істотно знижується. Але за зниженої мінералізації води ці процеси потребують меншої кількості витраченої енергії.

Отримані результати можна використати для біомоніторингу водойм, де відмічається перевищення температурного режиму вище кліматичної норми. На основі цього можна буде спрогнозувати зміни, які відбуваються у популяціях цього виду, зокрема, якісного та кількісного складу. Також отримані результати можна використовувати для оцінки фізіологічного стану в умовах глобальних змін клімату і спрогнозувати перебудову у структурі ії̈ популяцій. метаболізм

Ключові слова: плітка, глікоген, ліпіди, білок, температура, мінералізація,

Життєдіяльність і метаболізм гідробіонтів, у тому числі й риб, нерозривно пов'язані 3 характеристиками водного середовища $[6,11]$. Одними з головних складових показників водних екосистем, що впливають на загальний стан водних організмів, у тому числі й риб, є температура і гідрохімічний склад води. Значні зміни цих чинників середовища можуть викликати негативну дію на екологічні складові водних екосистем, а саме на якісний і кількісний склад іхтіофауни, фізіологічний стан риб та змінювати всі екологічні складові водних екосистем [13].

Для біомоніторингу водойм використовують низку досліджень, зокрема, пов'язаних із діагностикою фізіолого-біохімічного стану гідробіонтів. Одним із таких показників може бути вміст енергозапасаючих речовин в організмі риб. Саме завдяки цим характеристикам

(C) Худіяш Ю., Причепа М., Потрохов О., Зіньковський О., 2018 
Ю. Худіяш, М. Причепа, О. Потрохов, О. Зіньковський ISSN 0206-5657. Вісник Львівського університету. Серія біологічна. 2018. Випуск 79

фіксують і прогнозують рівні зміни фізіолого-біохімічного стану організму за впливу чинників водного середовища.

Останнім часом широко застосовують подібні дослідження для оцінки якості водного середовища. Це пояснюється тим, що за допомогою зазначених показників можна отримати узагальнюючу характеристику фізіологічного стану організму в конкретних умовах існування. Також результати подібних моніторингових досліджень дають змогу вирішувати проблеми, які стосуються встановлення наслідків негативної дії екологічних і антропогенних чинників на водні екосистеми.

Таким чином, метою наших досліджень було визначення залежності між вмістом глікогену, білка й загальних ліпідів і впливом одночасної зміни температури та мінералізації води.

Вибір цих чинників середовища пов'язаний із тим, що внаслідок глобальних кліматичних змін відбулися певні зміни середньостатистичної температури повітря та, відповідно, води $[16,20]$. Також за цих умов змінюється і йонний склад води природних екосистем, у деяких випадках відбувається підвищення мінералізації води через процеси ії випаровування або опріснення за надмірних атмосферних опадів [5]. Саме вміст глікогену, білка та загальних ліпідів у тканинах може вказувати на спрямованість енергетичного обміну у риб i, певною мірою, дасть змогу оцінити фізіологічний стан їхнього організму за значних змін температури й мінералізації води.

\section{Матеріали та методи}

Дослідження проводили на Білоцерківській експериментальній гідробіологічній станції Інституту гідробіології НАН України у червні 2017 року. Об’єктами дослідження були трилітки плітки Rutilus rutilus, Linnaeus, 1758. Для досягнення поставленої мети проведено серію експериментів в акваріумах об'ємом 60 дм $^{3}$ із різною мінералізацією води $240 ; 350 ; 520$ мг/дм ${ }^{3}$ і 3 коливальним добовим режимом температури води 21-23; 25-30; 27-32 ${ }^{\circ} \mathrm{C}$. Варто зазначити, що температуру води протягом 12 год підтримували на вищому температурному рівні за допомогою водяних нагрівачів, а в наступні 12 год відбувалося іiі охолодження на $2-5{ }^{\circ} \mathrm{C}$.

У кожен акваріум було посаджено по 8 екз. риб. Кисневий режим підтримували за допомогою мікрокомпресорів. Беручи до уваги, що розчинність кисню прямо залежить від температури, відповідно, концентрація його в дослідах була неоднакова. Так, за діапазону температури $21-23{ }^{\circ} \mathrm{C}$ вміст кисню у воді був на рівні 6-7 мг/дм ${ }^{3}$, а за температури води $30-$ 25 і $27-32{ }^{\circ} \mathrm{C}$ становив 5-6 і 4,5-5 мг/дм³ , відповідно, що не є критичним для цього виду риб.

Для зменшення накопичення продуктів метаболізму риб у воді кожної доби проводили заміну 1/3 води від загального об'єму з додаванням такої ж самої кількості води. Риб годували личинками хірономід.

На 14-ту добу експерименту для біохімічних досліджень було відібрано зразки тканин риб, а саме печінка та білі м'язи. У лабораторних умовах проводили визначення вмісту глікогену антроновим методом [10], загальних ліпідів у тканинах печінки з використанням фосфорно-ванілінового реагента за допомогою стандартних комерційних наборів “Загальні ліпіди» («Філісіт-Діагностика»). Вміст білка визначали за методом Лоурі [19]. Статистичну обробку даних проводили за допомогою програми Statistica 5.5. Під час проведення експерименту було дотримано всіх норм біоетики.

\section{Результати і їхнс обговорення}

Одним із головних факторів, від яких залежить інтенсивність обмінних процесів гідробіонтів, у тому числі й риб, є температура навколишнього середовища $[3,11]$. Резуль- 
тати наших досліджень вказують на різноспрямовану відповідь організму плітки на зміни температури і мінералізації води.

Так, вміст загального білка у тканинах м'язів риб піддослідних груп за температури 21-23 ${ }^{\circ} \mathrm{C}$ і мінералізації 350 і 560 мг/дм³ майже не відрізнялися між собою (рис. 1). Проте у риб, які перебували у воді з мінералізацією 260 мг/дм³ загального білка в м'язах на 40 \% порівняно з особинами, які перебували у воді з більшою мінералізацією.

Високий вміст загального білка у м’язах плітки за нижчої мінералізації вказує на переважання у м'язах плітки процесів анаболізму білка над катаболізмом. Це явище можна пояснити більшою інтенсивністю біосинтетичних процесів, спрямованих на ріст риб; вона $\epsilon$ наслідком зниження мінералізації води, яка за цієї температури більш відповідає нормальному перебігу метаболічних процесів у цього виду риб.

За підвищення температури води до 25-30 ${ }^{\circ} \mathrm{C}$ і максимальної мінералізації води вміст загального білка у м'язах риб не змінювався порівняно з попередньою температурою. Але в умовах нижчої мінералізації від 260 до 350 мг/дм³ вміст білка у м’язах плітки зростав. Це, у свою чергу, вказує на сприятливість цих умов для проходження білкового обміну у плітки. Подальше підвищення температури до $27-32{ }^{\circ} \mathrm{C}$ зумовлювало значне збільшення вмісту білка за мінералізації 520 мг/дм³. Це, ймовірно, пов'язано з істотними витратами інших енергозапасаючих речовин (глікогену та ліпідів) у м'язах плітки для підтримання гомеостазу в несприятливих температурних умовах. У той же час за нижчої мінералізації (260-350 мг/дм³) посилюються процеси катаболізму білків для підтримання енергетичного балансу в адаптаційних процесах до несприятливого чинника. За цих умов спостерігаємо зниження вмісту загального білка у м'язах плітки на 14,8 та 24,9 \%, відповідно, порівняно 3 попереднім температурним діапазоном $\left(25-30{ }^{\circ} \mathrm{C}\right)$. У попередніх дослідженнях [8] було виявлено, що зі зростанням температури води за мінералізації 260 мг/дм³ у плітки відбувалося зростання вмісту глюкози у плазмі крові. Очевидно, внаслідок розпаду білка до амінокислот відбувалося поновлення енергетичних запасів у вигляді глюкози за рахунок глюконеогенезу, адже глюкоза є найдоступнішим джерелом енергії для більшості живих організмів [2, 9].

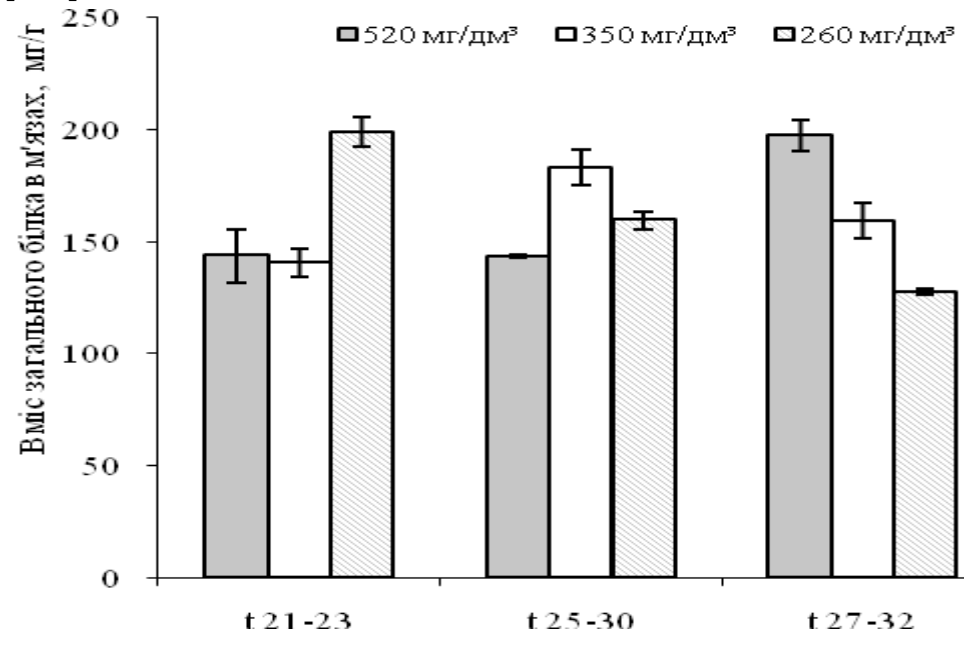

Рис. 1. Вміст загального білка у м'язах плітки, $\mathrm{M} \pm \mathrm{m}, \mathrm{n}=5$ 
Ю. Худіяш, М. Причепа, О. Потрохов, О. Зіньковський

У процесі життєдіяльності риб білки виконують різноманітні функції, до яких входить також енергетичне забезпечення. Так, під час розщеплення 1 г білка виділяється приблизно 16,7 кДж енергії [7]. Очевидно, значне використання білків як джерела енергозабезпечення викликане посиленням енергетичних потреб метаболічних процесів унаслідок зростання температури зовнішнього середовища.

Таким чином, найсприятливішими для плітки за показниками білкового обміну є коливання температури в межах 21-23 ${ }^{\circ} \mathrm{C}$ та мінералізація води на рівні 260 мг/дм ${ }^{3}$. Ці умови найбільш поширені в ареалі розповсюдження виду. За досить високої температури (25-30 $\left.{ }^{\circ} \mathrm{C}\right)$ та в умовах мінералізації води на рівні 520 мг/дм ${ }^{3}$ не спостерігається суттєвих відмінностей показників вмісту білка у білих м'язах порівняно з оптимальними екологічними чинниками. Проте за доволі низької мінералізації води (260-350 мг/дм³) спочатку відбувається збільшення вмісту білка за температури $25-30{ }^{\circ} \mathrm{C}$, що свідчить про посилення росту риб. За подальшого збільшення температури води білок активно застосовується в енергетичному обміні.

Встановлено, що вміст загальних ліпідів у печінці піддослідних груп риб, які перебували у воді з мінералізацією 350 та 520 мг/дм ${ }^{3}$ у у температурному діапазоні $21-23{ }^{\circ} \mathrm{C}$ не відрізняються. За найменшої мінералізації 260 мг/дм³ у дослідних риб вміст загальних ліпідів зменшувався у 2,3 разу порівняно з попередніми умовами (рис. 3). При цьому за цієї мінералізації води вміст глікогену був значно вищим (у середньому в 1,6 разу), ніж у піддослідних груп із вищими рівнями мінералізації (350 і 520 мг/дм³) (рис 2).

Із літературних джерел відомо, що глікоген і загальні ліпіди мають важливу роль в акумуляції та мобілізації резервної енергії у тварин. Слід відмітити, що глікоген $є$ найбільш доступним енергетичним субстратом, який в основному використовується для забезпечення енергією енергозатратних процесів. Для забезпечення тривалих енергогенеруючих процесів або в умовах зимівлі риб більше використовуються загальні ліпіди $[14,15]$. Так, з 1 г глікогену організм виробляє 16,7 кДж, а з 1 г ліпідів - 37,7 кДж енергії. Очевидно, в оптимальних умовах енергетичне забезпечення організму риб переважно відбувалося за рахунок ліпідів, адже воно $є$ найбільш енерговигідним. При цьому зростання вмісту глікогену в печінці плітки напряму пов'язане зі значним використанням ліпідів на енергозабезпечення процесів метаболізму.

Загальновідомо, що продукти метаболізму ліпідів частково можуть включатися в біосинтез глюкози $[2,4,22,23]$. Таким чином, значне використання загальних ліпідів на процеси енергозабезпечення зумовило зростання продуктів метаболізму, які активно почали використовуватися на синтез глюкози, що, відповідно, в подальшому призвело до зростання вмісту глікогену в печінці плітки. Це, зокрема, підтверджується попередніми дослідженнями [8].

За збільшення температури води зміни вмісту енергозапасаючих сполук у тканинах плітки мали інші закономірності. За температурі води $25-27^{\circ} \mathrm{C}$ та мінералізації води 520 мг/дм³ вміст загальних ліпідів і глікогену в печінці не змінюється порівняно 3 попереднім температурним режимом. Але за нижчої мінералізації води вміст цих речовин у печінці істотно зростає - на 21,3-33,0 \% та 31,1-155,9\%, відповідно.

Очевидно, значне підвищення вмісту ліпідів у печінці є наслідком зменшення енергетичних потреб метаболічних процесів за підвищення температури води зовнішнього середовища. Особливо помітно, що за температури води $25-30{ }^{\circ} \mathrm{C}$ та зниженої мінералізації води істотно зростає вміст глікогену в печінці - на 47,1-76,7 \%, порівняно з температурою $21-23{ }^{\circ} \mathrm{C}$. Відоме явище значного накопичення ліпідів і глікогену у тканинах коропових риб за тепловодного вирощування [12], що і спостерігається в нашому випадку. 
Ю. Худіяш, М. Причепа, О. Потрохов, О. Зіньковський ISSN 0206-5657. Вісник Львівського університету. Серія біологічна. 2018. Випуск 79

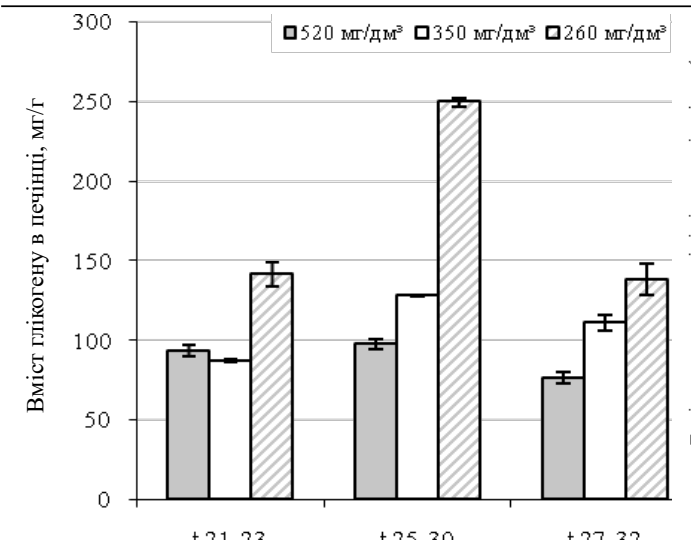

Рис. 2. Вміст ґ.

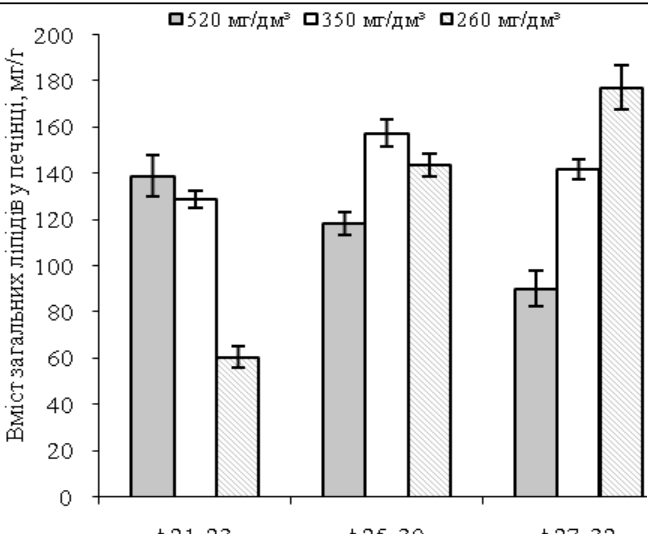
$\mathrm{n}=5$

$$
\mathrm{M} \pm \mathrm{m}, \mathrm{n}=5
$$

Подальше підвищення температури води до рівня $27-32{ }^{\circ} \mathrm{C}$ зумовлювало зниження вмісту глікогену в печінці усіх піддослідних груп, особливо за мінералізації $260 \mathrm{мг/дм³}$, на 80,9 \% порівняно з попереднім температурним режимом. Температура води досягла таких значень, що для підтримання гомеостазу організму необхідно застосовувати компенсаторні механізми адаптації риб до діючого чинника, які потребують значних енергетичних витрат.

У той же час для адаптації до підвищеної температури використовуються ліпіди лише за доволі високої мінералізації 350-520 мг/дм³, а за 260 мг/дм їхня кількість продовжувала зростати. Це свідчить, що умови низької мінералізації води більш сприятливі для плітки і що на пристосування до температурного чинника не потрібні значні енерговитрати.

Таким чином, якщо розглядати закономірності адаптації риб до температурного режиму, помітно, що на перших етапах пристосування плітки до помірних температур $\left(25-30{ }^{\circ} \mathrm{C}\right)$ вміст цих сполук або залишається на попередньому рівні, або зростає залежно від мінералізації води. На другому етапі, коли температура води значно перевищує кліматичні рівні та досягає $27-32{ }^{\circ} \mathrm{C}$, для успішної адаптації до наявних умов потрібні додаткові енерговитрати, вміст запасних речовин і, в першу чергу, глікогену, який істотно знижується. Але за зниженої мінералізації води ці процеси потребують меншої кількості витраченої енергії.

Крім того, вміст глікогену в печінці плітки за різних температурних режимів залежить і від особливостей метаболічного перетворення енергетичних сполук в організмі. Із літературних джерел відомо, що для енергозабезпечення адаптаційних процесів можливе спільне використання як вуглеводних, так і білкових субстратів [8]. У деяких випадках використовується білок на енергозабезпечення метаболічних процесів. Це у подальшому може призводити до зростання вмісту глюкози у плазмі крові, яка, у свою чергу, буде використана як енергетичне джерело для урівноваження тканинного гомеостазу. При цьому варто відмітити, що за спільного споживання глікогену і білкових субстратів відбувається відновлення рівня глікогену у процесах глюконеогенезу за рахунок збільшення частки використання білка $[1,20,21]$. У свою чергу, продукти білкового та вуглеводневого метаболізму можуть використовуватися на синтез ліпідів $[17,18]$. Таким чином, залучення білкових субстратів і глікогену на енергетичні потреби організму сприяли зростанню загального пулу ліпідів за рахунок використання продуктів метаболізму білкового та вуглеводного обміну.

Також збільшення вмісту ліпідів у тканинах печінки плітки може бути пов'язане 3 безпосередньою дією температурного чинника на процеси ліпідного обміну. Так, із літе- 
ратурних даних відомо, що за тепловодного вирощування риб відбувається метаболічне підсилення синтезу ліпідів. Головними причинами підвищення зазначеного синтезу може бути інтенсифікація гліколітичних процесів, підвищення розпаду таких регуляторів ліпідного обміну, як холін, а також зростання функціональної активності симпатико-адреналінової системи [12].

Таким чином, значне підвищення температури води, що спостерігається на мілководних ділянках водойм у період надмірної температури, може мати негативні наслідки для метаболізму у цього виду та спричинити виснаження організму.

За результатами проведених досліджень можна зробити висновок, що температурний чинник мав більший вплив на вміст енергетичних субстратів, ніж мінералізація води. При цьому слід відмітити, що сумісна дія температури і мінералізації води мала більший ефект впливу на баланс вмісту глікогену, ліпідів і білка, ніж їхня окрема дія. У свою чергу, знижена мінералізація води більш сприятлива для обмінних процесів у плітки.

Нами також відмічено, що для кожної мінералізації води була притаманна своя температура, за якої вміст глікогену, ліпідів і білка мав найвищі показники. Так, якщо порівнювати за вмістом загального білка у тканинах, який $є$ одним із головних ростових показників, то найбільший його вміст був зафіксований у риб, які перебували у воді з мінералізацією $260 \mathrm{мг} /$ дм $^{3}$ і за температурного діапазону $21-23{ }^{\circ} \mathrm{C}$. За мінералізації води $350 \mathrm{мг} /$ дм $^{3}-$ значний ріст вмісту білка спостерігався у плітки, яка була у воді з температурою $25-30{ }^{\circ} \mathrm{C}$. За температури води $27-32{ }^{\circ} \mathrm{C}$ відмічено його зростання у тканинах плітки, яка перебувала у воді 3 мінералізацією 520 мг/дм³.

Варто відмітити, що значне підвищення температурного чинника призводить до дисбалансу вмісту енергетичних субстратів у тканинах плітки. Особливо це було характерно для піддослідних груп, які перебували у воді з температурою $27-32{ }^{\circ} \mathrm{C}$. Відмічене нами порушення здатне викликати негативні фізіолого-біохімічні наслідки, що в подальшому може призвести до летальних явищ [15].

За результатами досліджень встановлено, що сумісна дія температури і мінералізації води більш суттєво впливає на процеси синтезу та катаболізму енергетичних субстратів, ніж їхня окрема дія. Особливо це було характерно для піддослідних груп, які перебували за нетипової та підвищеної температури води $27-32{ }^{\circ} \mathrm{C}$ і низької мінералізації 260 мг/дм ${ }^{3}$. За цих умов спостерігається вагоме зростання вмісту загальних ліпідів у печінці у 2,3 та 2,9 рази порівняно з рибами, які перебували за $21-23{ }^{\circ} \mathrm{C}$ та $25-30{ }^{\circ} \mathrm{C}$.

Для плітки оптимальними умовами в літній період є температура води $21-23{ }^{\circ} \mathrm{C}$ та iii мінералізація на рівні 260 мг/дм³ 3 підвищенням температури води настає дисбаланс утилізації або накопичення запасних речовин. На надмірну температуру та підвищену мінералізацію води риби реагують як на суттєвий стрес-чинник, який може викликати виснаження організму.

Таким чином, отримані результати засвідчили, що фізіолого-біохімічний стан риб підлягає суттєвим коливанням залежно від сили і тривалості дії конкретних чинників, що має враховуватися під час проведення біомоніторингу. Оскільки плітка є промисловим видом риб, отримані результати можна використовувати для оцінки фізіологічного стану в умовах глобальних змін клімату і спрогнозувати перебудову у структурі їі популяцій.

\section{СПИСОК ВИКОРИСТАНОЇ ЛІТЕРАТУРИ}

1. Горомосова С. А., Шапиро А. 3. Основные черты биохимии энергетического обмена мидий. М.: Легкая и пищевая пром-сть, 1984. 120 с. 
2. Губський Ю. М. Біологічна хімія. Київ;Вінниця: Нова книга, 2007. 191 с.

3. Ивлева И. В. Влияние температуры на скорость метаболизма пойкилотермных животных // Успехи соврем. биологии. 1972. Вып. 1. С. 134-136.

4. Коваль B. A. Изменения биохимических параметров карпа при действии повышенных концентрацій аммиака // Біорізноманіття та роль тварин в екосистемах: Матеріали V Міжнар. наук. конф. Дніпропетровськ: Ліра, 2009. С. 113-114.

5. Курило С. М. Основні тенденції багаторічних змін мінералізації води та вмісту головних іонів у річках України // Гідрохімія. Гідрологія. Гідроекологія. 2016. Т. 2. № 41. С. $85-90$.

6. Лукьяненко В. И. Общая ихтиология. М.: Легкая и пищевая пром-сть, 1986. 317 с.

7. Меилер Д. Биохимия. Химическая реакция в живой клетке. М.: Мир, 1980. 488 с.

8. Потрохов О. С., Зіньковський О. Г., Худіяш Ю. М., Причепа М. В. Особливості пристосування риб до зміни температури і мінералізації води за показниками вмісту трийодтироніну, кортизолу і глюкози у плазмі крові // Наук. записки Тернопіль. нац. пед. ун-ту ім. В. Гнатюка. 2017. Т. 1. № 68. С. 89-95.

9. Потрохов О. С., Зіньковський О. Г., Худіяш Ю. М., Пустовгар В. П. Вплив підвищеної солоності води на вміст глікогену у печінці прісноводних риб // Биоразнообразие и устойчивое развитие: Материалы Ш науч.-практ. конф. (г. Симферополь, 15-19 сентября 2014 г.). Симферополь, 2014. С. 286-288.

10. Практикум по биохимии: учеб. пособ. / под ред. С.Е. Северина, Г.А. Соловьевой. М.: Изд-во МГУ, 1989. 509 с.

11. Романенко В. Д., Арсан О. М., Соломатина В. Д. Механизмы температурной акклимации рыб. К.: Наукова думка, 1991. 192 с.

12. Романенко В. Д. Эколого-физиологические основы тепловодного рыбоводства. К.: Наук. думка, 1983. 140 c.

13. Сергеева Н. Р., Лукьяненко В. И. Общая ихтиология. Краснодар, 2008. 157 с.

14. Шульман Г. Е., Токарев Ю. Н. Функциональное разнообразие как важный фактор существования биотических компонентов экосистем // Морський екологічний журнал. 2006. № 1. Т. 5. С. 35-56.

15. Элементы физиологии и биохимии и активного обмена у рыб. К.: Наукова думка, 1978. 204 c.

16. Abraham J. P. A review of global ocean temperature observations: Implications for ocean heat contentes timates and climate change// Rev. Geophys. 2013. Vol. 51. N 3. P. 450-483.

17. Fokina N., Nemova N., Nemova Z. Fatty acid composition of mussels Mytilus edulis under short term anoxia // Chemistry and physics of lipids. Abstracts from 48th Int. Conf. on the Bioscience of Lipids (Turku, Finland, 4-8 sept. 2007). Turku, 2007. Vol. 149. P. 60.

18. Michaelidis B., Pallidou A., Vakouftsi P. Effects of anoxia on the extra and intracellular acid_base status in the land snail Helix lucorum (L.): lack of evidence for a relationship between pyruvat kinase down_regulation and acid_base status // J. Exp. Biol. 1999. Vol. 202. P. 1667-1675.

19. Lowry O. H., Rosenberg N. J., Farr A. L., Randall R. J. Protein measurement with the folin phenol reagent // J. Biol. Chem. 1951. Vol. 193. N 1. P. 265-275.

20. Shcherbak V. I., Zadorozhnaya A. M., Kalenichenko K. P. Phytoplankton Spatial and Temporal Dinamics in the Additional Net of the Kiev Section of the Kanev Reservoir // Hydrobiological J. 2014. Vol. 50. N 3. P. 3-12.

21. Teerijoki $H$. Fish glucose transporters: molecular cloning and functional characterization $/ / \mathrm{C}$. Natural and Environmental Sciences. 2002. Vol. 140. P. 75. 
22. Zwaan A., de Wijsman A. Anaerobic metabolism in Bivalvia (Mollusca). Characteristics of anaerobic metabolism // Comp. Biochem. Physiol. 1976. 54 B. P. 313-324.

23. Zwaan A., de Mathien A. Cellular energy metabolism in the Mytilidae - an overview. The mussel Mytilus ecology, physiology, genetics and culture. Elsevier, Amsterdam, 1992. P. 143-155.

Стаття: надійшла до редакиії 19.01.18

доопрацьована 02.08.18

прийнята до друку 10.09.18

\title{
CHANGE IN THE CONTENT OF GENERAL LIPIDS, GLUCOGENE AND PROTEIN IN THE FOOT TISSUE OF RUTILUS RUTILUS, LINNAEUS, 1758 FOR THE COMPATIBLE ACTION OF TEMPERATURE AND MINERALIZATION OF WATER
}

\author{
Y. Khudiiash, M. Prychepa, O. Potrokhov, O. Zinkovskyi \\ Institute of Hydrobiology, NAS of Ukraine \\ 12, Heroes of Stalingrad Ave., Kyiv 04210, Ukraine \\ e-mail: email:yurahud@ukr.net
}

The joint effect of temperature and water mineralization on the content of glycogen, lipids and protein, in gut tissues Rutilus rutilus, Linnaeus, 1758 is considered. As a result of the studies, it has been established that the combined effect of water temperature and mineralization have a greater effect on the balance of energy-intensive compounds than their separate action. This was particularly characteristic of experimental groups that were at an unusual and elevated water temperature of $27-32{ }^{\circ} \mathrm{C}$ and a low mineralization of $260 \mathrm{mg}$ / $\mathrm{dm}^{3}$. It is shown that for roach the more optimal conditions in the summer are the water temperature of $21-23{ }^{\circ} \mathrm{C}$ and its mineralization at $260 \mathrm{mg} / \mathrm{dm}^{3}$. As the water temperature rises, there is an imbalance in the utilization or accumulation of reserve substances.

It was found that the involvement of protein substrates and glycogen in the energy needs of the body contributed to the growth of a common pool of lipids due to the use of protein metabolism products and hydrocarbon metabolism. It was shown that in the first stages of adaptation of roach to moderate temperatures $\left(25-30^{\circ} \mathrm{C}\right)$ the content of these compounds or remains at the previous level, or increases depending on the mineralization of water. In the second stage, when the water temperature significantly exceeds the climatic levels and reaches $27-32{ }^{\circ} \mathrm{C}$, for successful adaptation to the existing conditions, additional energy consumption, the content of the spare substances and, first of all, glycogen, which is significantly reduced, is required. With reduced water mineralization, these processes require a smaller amount of energy expended.

The obtained results can be used for biomonitoring of reservoirs, where an excess of the temperature regime is noted above the climatic norm. Based on this, it will be possible to predict the changes that occur in populations of this species, in particular qualitative and quantitative composition. Also, the results can be used to assess the physiological state in conditions of global climate change and predict the restructuring in the structure of its populations.

Keywords: roach, glycogen, lipid, protein, temperature, mineralization, metabolism 